\title{
A Profile of Academic Libraries in China
}

\author{
Thomas Y. Yeh
}

Operating under rules issued from the central government in Beijing, academic libraries in China share common characteristics and problems. These libraries lag behind the United States in budget, personnel management, building design, and public services. On the other hand, the use of academic libraries is very high. China has placed a high priority on academic library services and should greatly improve its library systems within a decade.

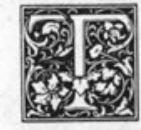

here were 675 colleges and universities in the People's Republic of China (PRC) in 1980 and $1,143,700$ college students. In 1982 the number of colleges and universities had increased to 715 and there were $1,540,000$ college students. College students are a small and elite group among China's population of over one billion. Almost all colleges and universities are public institutions, i.e., either supported by the central government in Beijing, or supported by provincial and city government. Private colleges and universities are rare. Each college and university has a library. Though academic libraries vary in size and their services differ, all share some common characteristics and problems.

In China everything is regulated by the central government in Beijing. For example, there is only one time zone. If it is one o'clock in Beijing, it is also the same time in Urumqi, Xinjiang Province located fifteen hundred miles away. So, regardless of the position of the sun, everyone in China wakes up, does exercises, and begins work at the same time. The college and university libraries are no exception; they too are all operated under the rules and regulations issued from Beijing. Among these regulations is the People's Republic of China Higher Education Institutions' Library Working Regulation.
Composed of thirty articles, this regulation was issued by the Ministry of Education on October 15, 1981.

Article one of this document states that in an institution of higher education the library is the center for its books and resources. As an academic unit its function is a vital component of teaching and the research process. This is quite a departure from the past. In the 1950 s, following the establishment of the PRC, China's libraries were open to workers, peasants, and soldiers as well as the college community. In the disastrous Cultural Revolution years (1966-1976), many universities were closed. Librarians and other scholars were sent to the country to do manual labor, while factory workers ran the colleges and universities. Libraries were reopened after the Cultural Revolution, and the current mission of Chinese college and university libraries is in line with library philosophy in the United States.

Article fifteen of the PRC regulation also states that each academic library should establish a branch Communist party that reports directly to the College Party Committee. The branch party is responsible for the party's membership and political thought indoctrination. The branch party conducts a political study session every Saturday afternoon for all library staff. Usually the staff studies current political

Thomas $Y$. Yeh is associate professor and head of the documents department at Central Washington University, Ellensburg, Washington 98926. The author taught and traveled in China from December 1983 to July 1984 as an exchange professor at the Anhui University Library. 
documents such as the premier's address to the People's Congress. Sometimes the library staff joins the rest of the college in a Saturday afternoon rally sponsored by the College Party Committee. A patriotic speech is often delivered by an invited guest speaker.

The Library Branch Party Committee also protects and oversees the library's functions. Any staff member not in conformity with the official ideology or guidelines would be criticized and reported to the College Party Committee. The same applies if work performance does not meet the standards imposed by the official guidelines.

A typical academic library building is made of concrete and is less than five stories high. The priorities of building design are functionality and minimal cost. There are few frills. Since electricity is expensive, library buildings are designed to use natural light as much as possible. As a result, many university libraries are U-shaped with inner courts.

Library furniture and equipment are generally old and in need of repair or replacement. Central air conditioning is almost nonexistent and carpeting is a luxury few libraries can afford. By order of the central government only libraries north of the Huaihe River can have heat. Libraries in the warmer south and all other university buildings have no heat. This somewhat arbitrary division of north and south produces some hardship. For example, temperatures in the southern city of Shanghai often fall below freezing in the winter. During the cold season, patrons of academic libraries generally keep their warmest clothing on inside library buildings.

Academic libraries are very crowded. In 1980 there were only $1,323,300$ square meters of space in these libraries. On the other hand, 79 colleges and universities were adding a total of 421,600 square meters of library space and 188 colleges and universities were planning to add another 871,200 square meters of library space. ${ }^{1}$ There was a total of $193,621,300$ volumes in China's academic libraries in 1980. Of this total, $8,818,700$ volumes were waiting to be cataloged. Also, 22,229,900 volumes of cataloged materials were not shelved because there was no space for them. ${ }^{2}$

In the United States, 60 percent to 80 percent of the academic library budget is for salaries and 20 percent to 40 percent for books and operating costs. In contrast, 60 percent to 80 percent of the Chinese academic library budget is spent on books and only about 20 percent to 40 percent on salaries and operating costs.

Staff salaries are regulated by the central government. A salary scale with twentysix grades has been established. This scale is applied to all civil service employees: teachers, librarians, and others. An entrylevel college graduate's salary is 50 yuan. This is equivalent to $\$ 25$ a month. High school graduates receive less. Very few Chinese academic librarians make over 150 yuan a month. Low salaries are not limited to librarians. College professors receive the same salary.

While the salaries for Chinese librarians are very low, the cost of living is far lower in China than in the United States. The monthly rent for a one room apartment is 5 yuan. This is equivalent to $\$ 2.50$ a month.

The budgets of China's academic libraries are limited compared to the United States. In 1980 the total budget for 670 libraries was about $\$ 28.8$ million or $\$ 40,000$ per library. Forty-seven percent of all academic libraries had budgets under $\$ 25,000 ; 30$ percent had budgets between $\$ 30,000$ and $\$ 50,000$ and only 1 percent had budgets over $\$ 250,000$. Only 13 percent had more than 5 percent of the total instructional budget of the college or university. Fifteen percent had between 4 and 5 percent of the total instructional budget and the rest were under 4 percent. ${ }^{3}$

Because college students and professors have limited incomes, few can afford to buy books. Students and faculty depend entirely on libraries to provide instructional support. Therefore, academic libraries usually purchase multiple copies of books: five, ten and even thirty copies of a book are common. Because the price of foreign books is high and the demand for them is low, usually only one copy is purchased by the library.

Collection development is closely tied to various political campaigns. When a political campaign begins, many books relating 
to the campaign are purchased. When another political campaign begins, the old literature is considered incorrect and is removed from the library. It may even be destroyed. During the Cultural Revolution, the Red Guards removed and destroyed many foreign language books since they were considered decadent, capitalistic, and imperialistic dogma.

A recent campaign was the AntiSpiritual Contamination Movement from 1983 to early 1984 . This campaign was a mild one compared to the Cultural Revolution. Some books, especially those considered pornographic, were removed. One library transferred the Chinese translation of Sir Winston Churchill's memoirs of World War II from the general collection to the Internal Book Room, the equivalent of our special collections. Only students in a World War II history class or students with special permission were able to check out this title.

There are many rare books in Chinese libraries. However, their condition is unknown and they may be in jeopardy. There is no air conditioning. Only library buildings in the north may have heat and there are no special temperature or humidity-controlled rooms. Many old and rare volumes are deteriorating. Some date back over eight hundred years. The pages of these volumes are fragile from long exposure to the elements. Since most libraries do not have effective fire protection systems, any fire would be a major disaster.

The use rate of academic libraries is extremely high. Reading rooms are crowded. Virtually every seat is occupied within minutes after a library opens. Some large classrooms are opened in the evening and designated as study areas.

Circulation statistics are also high since most academic libraries have closed stacks and browsing is limited. There are usually limitations to the number of volumes a student or faculty member can borrow at one time. Occasionally borrowing is restricted to one's major field of study or research.

During the Cultural Revolution, China went through a period of dramatic experimentation. All colleges and universities were closed from 1966-1971. Students and faculty were sent to farms to do manual labor. The colleges and universities were reopened in 1972, but regardless of their intellectual and educational background, students were enrolled only on the recommendation of workers, peasants, and soldiers. Usually only children of the proletarian class were nominated. Children of the intelligentsia were held on the farms. China reinstated the competitive college entrance examination system in 1977 and the possibility of college admission was opened to all.

The Cultural Revolution was disastrous. Libraries were cut off from the outside world for ten years. They were closed, acquisitions ceased, and some collections destroyed. Academic librarians were usually sent to work on the farms. Today, there is still a ten-year gap in book and periodical collections, especially in western science and technology.

The retrieval of science and technology information is relatively inefficient. Scientists and engineers spend almost half of their research time doing literature searches. It is estimated that because of the inefficient systems of information retrieval 50 percent of science and technology research programs duplicate work already done in the West. ${ }^{4}$

China's academic libraries are well staffed, but few staff members have formal training in library science. In 1981 only 5 percent had a library science education. ${ }^{5}$ Nineteen colleges and universities offered two and four years undergraduate education programs in library science. ${ }^{6}$ The library science faculty numbered 177-1 professor, 17 associate professors, 63 assistant professors and 96 instructors.

Five years ago 17,297 staff members were employed in 670 academic libraries. 62 percent were female and 38 percent were male. Eighteen percent of the library staff were on full time or part-time leaves of absence because of illness or old age. Forty-two percent were senior high school graduates, 39 percent were college graduates, and 20 percent had only a junior high school education. The majority of the library staff was relatively inexperienced since many were hired after the Cultural Revolution. Fifty-six percent had less than five years of library experience. Twenty- 
five percent had more than fifteen years experience. ${ }^{8}$ The Cultural Revolution also created an age gap among academic librarians. Some are middle-aged, but the majority are either old or young.

Among the 1,085 academic library directors and deputy directors, only 8 percent had library science training. The others were primarily former college professors. The library directors and deputy directors tended to be older persons: 50 percent were between fifty-one and sixty, 28 percent were over sixty, 20 percent were between forty-one and fifty, and 1 percent were under forty.'

The Cultural Revolution also caused a disparity in the years of experience among directors and deputy directors. Forty-nine percent had less than five years of experience in the library; 22 percent had more than twenty years of experience, 17 percent had six to ten years of experience, and 13 percent had eleven to twenty years of experience. Twenty-one percent held faculty rank. Surprisingly, among 670 college and university libraries, 55 percent had a deputy director but no library director. 24 percent had neither a library director nor a deputy director. Someone else was in charge. ${ }^{10}$

All employees in China are appointed by the central or provincial government. In the past, libraries were not a high priority so the government sometimes assigned people who were unable to find or hold other positions. College graduates with low demand majors were put to work in the library. Old college professors who could no longer teach were assigned to the academic libraries. It was not uncommon for a significant percentage of library staff not to show up for work due to old age or poor health.

Like any other job in China, once a librarian is assigned a job, it is guaranteed for life. Rarely is anyone laid off or fired. A change of profession or a move to another library in another city is rare, if not impossible. There is no established, systematic, annual evaluation of performance. Salary raises are mainly based on seniority, with no merit pay or other incentives.

Public services need improvement. Li- braries are open fewer hours than in the United States. It is not unusual for a library to be closed for lunch and supper breaks. Wednesday afternoons are reserved for staff meetings and Saturday afternoons are reserved for political meetings. The number of missing books is high. Most libraries do not have a centralized reference department. Library users are almost entirely on their own in the library. In the entrance to the library there is always an employee who checks, and sometimes keeps, employee cards or student ID cards. On leaving, the card is returned after a book inspection. The academic library is not as accessible as in the United States.

Libraries are not automated. All processing is done manually. There is no standard machine-readable cataloging format. There are no bibliographic databases. A few academic libraries are, however, experimenting with automated circulation systems. The central government is now planning to build a national automated database and bibliographic network.

Academic libraries in China may seem out-of-date and may provide only limited services compared with the United States. Amazingly though, Chinese academic librarians can provide "adequate" library services with limited funding and under poor physical conditions. The spirit and dedication of Chinese academic librarians should be admired.

The most urgent need in the modernization of China's academic libraries is to upgrade the library staff, especially at the top administrative levels. Better qualified librarians and dynamic professional leadership are badly needed. China has placed a high priority on improving its library services. New library buildings are under construction. Younger and better qualified librarians are taking over the directorships. More money is being allocated. China's academic libraries are going through an expansion similar to American libraries in the 1960s. With proper planning and guidance, they should greatly improve during the next decade. 


\section{REFERENCES}

1. 1981 Quan Guo Gao Deng Xue Xiao Tu Shu Guan Gong Zuo Hui Yi Wen Ji (1981 Proceedings of National Higher Education Institution Libraries Conference). (Beijing: Quan Guo Gao Deng Xue Xiao Tu Shu Guan Gong Zuo Wei Yuan Hui Mi Shu Chu, 1981), p. 323.

2. Ibid., p. 319.

3. Ibid., p. 322.

4. Mingzhao Wang, "Jian Shao Da Hai Lao Zhen Zhi Ku, Shi Ke Ji Gong Zuo Zhe Di Gong Tong Yuan Wang" (Reduce the Labor of Retrieving a Needle in the Ocean is the Common Wish of Scientists and Engineers), Anhui Gao Xiao Tu Shu Guan 2:74 (1983).

5. 1981 Quan Guo Gao Deng Xue Xiao Tu Shu Guan Gong Zho Hui Yi Wen Ji, p. 121.

6. Ibid., p. 48.

7. Ibid., p. 123.

8. Ibid., p. 320.

9. Ibid., p. 321.

10. Ibid., p. 321. 